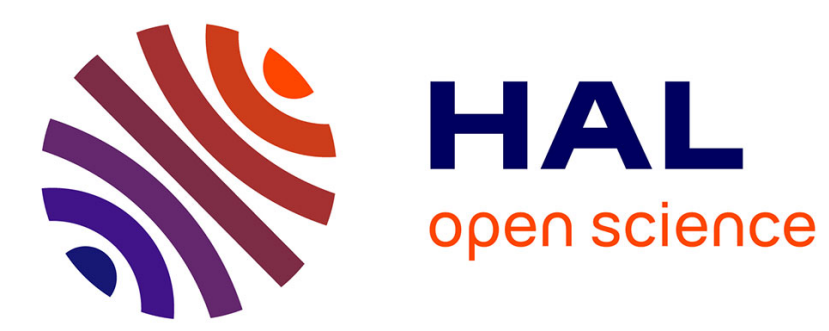

\title{
Fertility, Household Size and Poverty in Nepal
}

François Libois, Vincent Somville

\section{To cite this version:}

François Libois, Vincent Somville. Fertility, Household Size and Poverty in Nepal. 2017. halshs01662761

\section{HAL Id: halshs-01662761 https://shs.hal.science/halshs-01662761}

Preprint submitted on 13 Dec 2017

HAL is a multi-disciplinary open access archive for the deposit and dissemination of scientific research documents, whether they are published or not. The documents may come from teaching and research institutions in France or abroad, or from public or private research centers.
L'archive ouverte pluridisciplinaire HAL, est destinée au dépôt et à la diffusion de documents scientifiques de niveau recherche, publiés ou non, émanant des établissements d'enseignement et de recherche français ou étrangers, des laboratoires publics ou privés. 


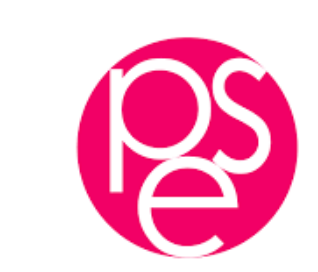

PARIS SCHOOL OF ECONOMICS
ECOLE D'ECONOMIEDE PARIS

WORKING PAPER N ${ }^{\circ} 2017-55$

Fertility, Household Size and Poverty in Nepal

François Libois

Vincent Somville

JEL Codes: I32 ; J13 ; D13 ; 053

Keywords: Nepal; Household size; Household composition; Poverty; Fertility

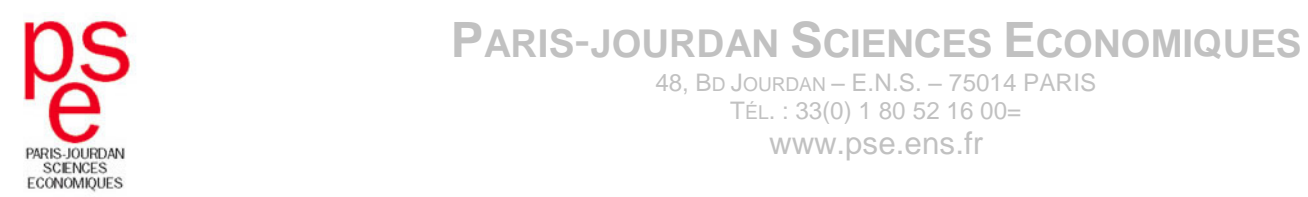




\title{
Fertility, Household Size and Poverty in $\mathrm{Nepal}^{*}$
}

\author{
François Libois ${ }^{\mathrm{a}, \mathrm{b}}$ and Vincent Somville $\mathrm{e}^{\mathrm{c}, \mathrm{d}}$ \\ ${ }^{a}$ CRED Namur University \\ ${ }^{\mathrm{b}}$ INRA Paris School of Economics \\ ${ }^{\mathrm{d}}$ NHH Norwegian School of Economics \\ ${ }^{\mathrm{c}}$ Chr. Michelsen Institute
}

November 24, 2017

\footnotetext{
${ }^{*}$ We are thankful to three anonymous referees, Arild Aakvik, Olivia Aubriot, JeanMarie Baland, Catherine Guirkinger, Magnus Hatlebakk, Sylvie Lambert, Peter Lanjouw, Jean-Philippe Platteau, Gilles Postel-Vinay, JoÃ«lle Smadja and Vincenzo Verardi for numerous comments as well as to seminar participants from CRED in Namur, CMI in Bergen, Heriott-Watt University, NTNU Trondheim, Bergen University, NHH - The Norwegian School of Economics and the NCDE conference in Helsinki. We acknowledge the financial support from the Research Council of Norway through the Econpop program and the PopPov network.
} 


\begin{abstract}
Population control policies keep attracting attention: by increasing the household size, having more children would directly contribute to a household's poverty. Using nationally representative household level data from Nepal, we investigate the links between a household's fertility decisions and variations in their size and composition. We show that the relationship between number of births and household size is positive when the mothers are young, but becomes negative as the mothers grow older. Elderly couples who had fewer children host, on average, more relatives who are outside the immediate family unit. This result sheds light on the heterogeneous relation between the number of children and household size over the life cycle. It also implies that reductions in a household's fertility may have an ambiguous impact on its per capita consumption, which depends on how the household's composition responds to new births and changes over time: in this sample, an old household's per capita consumption is not affected by the number of births. We use the gender of the first-born child to instrument the total number of consecutive children.
\end{abstract}

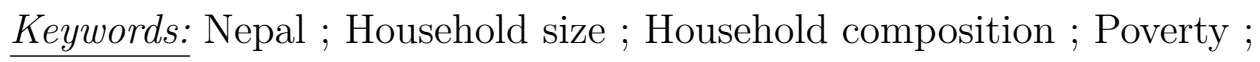
Fertility

JEL codes: I32 ; J13 ; D13 ; O53 


\section{Introduction.}

Insert figure 1 here

Figure 1, a poster of the India Ministry of Health and Family Welfare, is a good representation of low-fertility campaigns. Similar posters can be found in other countries or at other times. Shown on the left side is a family that has many children: that family is poor, badly dressed, living in a house that is in a very poor condition and with nothing growing on the surrounding land. On the right side is a family with only two children; this family looks much richer and happier. Poor and large families would not have the means to invest in the education of their children, or in the activities that generate their incomes. To get out of poverty, the poor should have fewer children. In many developing countries, a first glance at gross correlations confirms this link. In Nepal, we also observe a positive correlation between the number of children and household size as well as a negative correlation between these two variables and household income per capita.

Before spending resources on this kind of campaign or on more aggressive policies, as has been done in India and China, policy-makers ought to know exactly the channels through which reduced fertility might affect income per capita and, in terms of increased incomes and poverty alleviation, what benefits to expect. It is hard to understand why parents do not realize that having more children increases, in the short term, the size of their households as well as the number of unproductive mouths to feed and there- 
fore reduces income per capita. Nevertheless, they do have children. One important motive behind fertility, especially in developing countries, is the role played by children in helping to support the elderly. Children can be an investment strategy whose cost is supported in the short run, expecting long term benefits (Samuelson, 1958). Households might just want to increase quantity to maximize chances of being supported later on.

The quality-quantity trade-off is theoretically well understood (Becker et al., 1960). Empirically, the effects of changes in fertility on various outcomes linked to a household's welfare remain unclear: few studies have been conducted, and there is evidence in favour of (Joshi and Schultz, 2013) as well as against (Angrist et al., 2010, Black et al., 2005) the quality-quantity tradeoff. As explained by Schultz and Strauss (2007), a first order difficulty is that population policies tend to be national in scope and implemented in a nonrandom way, which complicates the finding of an adequate counter-factual. As these authors conclude from their review of the empirical literature, "Policies that help individuals reduce unwanted fertility are expected to improve the well-being of their families and society. But there is relatively little empirical evidence of these connections from fertility to family well-being and to intergenerational welfare gains, traced out by distinct policy interventions." They further stress that some outcomes of population policies "are likely to have a bearing on the way in which individuals form families and combine themselves into households. (..) Dealing appropriately with these complex behavioural issues opens an extensive agenda for microeconomic research" 
(Schultz and Strauss, 2007, p.3294-3297). One important limitation of existing studies is that they assume households are made of nuclear families, and they do not take into account that changes in fertility can have direct effects on the households' size and composition. Those effects are, however, crucial to understand, as they will have an impact on the final outcomes (for instance, the household per capita consumption).

We therefore focus on the influence of fertility on the size and demographic composition of households, and we show that births trigger important changes in the households' size and composition in Nepal. Among mothers aged 40 to 50, who thus have completed childbearing and represent roughly $18 \%$ of Nepali households, we find that those who have had more children live in smaller households. The data from the Nepal Living Standards Surveys show that couples who had fewer children tend to host more grand-children and in-laws than couples with more of their own children. Because households are parts of extended family networks, those who have fewer children simply host more other relatives. This finding concurs with the arguments of Cox et al. (2007), who emphasized the importance of kinship networks in redistributing resources. In our case, people, rather than goods or money, move between households.

The raw correlation between the number of children and the household size could suffer from endogeneity biases for various reasons. In particular, if some parents have a preference for larger households, they will have more children and welcome additional external members into their household. An 
even more serious concern arises when the opportunity cost of raising a child decreases with the household size. This would typically be the case if parents of the head live in the household and help in day care. Both examples would imply upward biased estimates of the coefficient of interest. We therefore need an exogenous source of variation in fertility to identify the causal effect of the number of children on the household's size and composition. To this end, we use the gender of the first-born as an instrumental variable, and we discuss its validity in Section 3.

Our findings reveal new complexities in the relationship between changes in fertility and poverty. The immediate effect of having more children is to increase the household size. However, households may also include various people such as grand-parents, uncles and aunts, cousins, grand-children, even people who are not blood-relatives. When a family has an additional child, some of the other people may move away (or may not come in). If a couple has few children at home they are likely to host more non-immediate family members or acquaintances. ${ }^{1}$

When the arrival of an additional child provokes the departure of another household member, or prevents hosting other relatives, it is not obvious anymore that the household will have fewer resources per person. This will depend on the relative consumption and generation of income of the child versus the member who left or did not join. We find that having an additional

\footnotetext{
${ }^{1}$ This argument is related to what anthropologists and biologists have called "cooperative breeding", see Kramer (2010). In economics, it is closely related to the argument of Cox et al. (2007) on the role played by kinship networks in the redistribution of resources.
} 
child increases the size of young households and is negatively associated with their per capita consumption. However, when mothers get older, there is no longer a relation between their number of children and per capita consumption.

Fertility decisions and the way a household composition and incomes vary with new births are context-dependent, and most likely, different families will adopt different behaviours. Childs (2001), for instance, describes how two geographically close villages in Nepal followed opposite trajectories in terms of population growth. In one village, parents designated their daughters to be nuns, barring them from marriage, while in the other village, young daughters were getting married and having children. Our goal here is to check whether a general pattern emerges across local differences and we focus on average effects over a large sample that covers most of Nepal's areas.

Other arguments have also been used to justify the public control of the size of a population. The influence of Malthus (1798) is strong, and many call for a limit on the world population given the limited amount of resources that are available. Those who contest this view generally argue that technological progress, which creates new resources and leads to more efficient ways to use then, must be taken into account. And a larger population may make creative ideas and technological progress more likely. Kremer (1993) supports this hypothesis and concludes that for most of human history, societies with larger initial populations indeed experienced faster technological change. We leave aside this debate to focus on the household-level dynamics that we 
outlined above.

We present the data in the next section and the identification strategy in Section 3. The empirical analysis is conducted in Sections 4 and 5. We further discuss the findings in Section 6, and we conclude in Section 7.

\section{Data and descriptive statistics.}

The Nepal Living Standards Surveys (NLSS) have been carried out in 1995/96, 2003/04, and 2010/11 by the Nepalese Central Bureau of Statistics in collaboration with the World Bank. The surveys follow the World Bank's Living Standards Measurement Survey methodology and cover a wide range of topics: demography, consumption, income, access to facilities, housing, education, health, employment, credit, remittances, etc. The quality of the surveys has been tested by Hatlebakk (2007), who also discusses them in greater details. The technicalities of the sampling, of the methodology, and of the execution of the surveys are exposed in CBS (2011a).

We use data from the three cross-sections and we focus on women who have completed childbearing (denoted old women). ${ }^{2}$ Information related to children ever born comes from a specific section of the questionnaire about women's maternity history. In that section, the respondent is asked about the number of children of each woman, the age of those children, their gender, whether they are still living within the household, and other demographic

\footnotetext{
${ }^{2}$ We do not have data on individual fertility status, but we instead use the age threshold of forty years old.
} 
information. Unfortunately this section is only administered to women below 50. Our estimation sample consists of 2123 old households: 454, 665, and 1004, respectively, from the first, second, and third survey, representing roughly $18 \%$ of Nepali households. We also report results on the sample of younger women. We have 6014 young households: 1611, 1808, and 2595 respectively, from the first, second, and third survey. The three surveys are referred to as T1, T2, and T3. All monetary values are corrected for inflation using local prices and reported in Nepalese Rupees of 2010 (NPR2010). ${ }^{3}$

\section{$2.1 \quad$ General picture}

Table 1 shows that the number of children is positively correlated with household size and negatively with income per capita. In Nepal, over 15 years, the mean income per capita more than tripled and the median almost doubled. This change over time is associated with both an increase in the absolute level of income and a significant reduction in household size. The average income increase is related to the expansion of non-farm activities and to growing in-flow of remittances (see CBS, 2011b). Note that the mean in the last survey is heavily influenced by a few extremely high incomes. The income of

\footnotetext{
${ }^{3}$ The original dataset contains information about 13273 households. A total of 4135 households are dropped from the dataset because their head has not yet had a child. From the remaining data, we lose 927 observations because the mother is too old (above 49 , and hence we miss the maternity data). We further discard households with twins. The results are not affected by the inclusion of households with twins, but they complicate the discussion and the interpretation of some results without generating any important insight. Finally, we lose 1 household with missing data about the age of the head. We also drop 14 polygynous households. The final number of observations is 8137 (2123 old and 6014 young).
} 
the 25th, 50th, and 75th percentiles, nonetheless, all increased steadily over the period, indicating similar decreases in poverty over the different initial levels of income. The average household size goes down from 6.13 members to 5.01. It correlates with a decline in fertility. On average, household heads have had 5.3 children in the first survey, 4.71 in the second survey and 4.06 in the last survey.

\section{Insert table 1 here}

As shown in figure 2, the cross-sectional correlations also support the positive correlation between the number of children and household size, as well as the negative correlation between number of births and income per capita. Figure 2 shows the mean household per capita income, by number of children. From this picture, it is clear that households that have between one and three children have, on average, higher incomes per capita than households with more than three children. There is, however, no clear difference in incomes between the households that have one, two, or three children. There is neither a difference in incomes among the households that have more than three children. The negative correlation between the number of children and household income per capita is consistent with the expectations that poorer parents decide to have more children to have a guaranteed support later in life. Furthermore, it could be that having more children increases the pressure on the household's resources, and decreases per capita income.

Insert figure 2 here 


\subsection{Household structure}

We use the following terminology in the analysis. A household comprises all people living together at the time of the survey. The term nuclear members refers to the head of the household, his/her spouse, and their children. Child and children are used to identify the sons and daughters of the household head. While a child is obviously younger than his father, children can be old. They comprise babies and infants but also adult children. We count all the children ever born, including those that were dead at the time of the survey. ${ }^{4}$

The typology of members is important in our paper since, in Nepal, people with various links to the head compose the household. In our sample, $55 \%$ of households match the stereotype underlying Figure 1 hosting a head, eventually his spouse and their children. On the other side, $45 \%$ of individuals live in a household that hosts at least one non-nuclear member. The number of households that match the right side of Figure 1 is, in fact, relatively small. Only $6.92 \%$ of the households have two children and live in a household that is only composed of the parents and their children. In addition to the nuclear family, households include mostly parents of the head, children-in-law, and grand-children. In Table A.1, we show how the household composition evolves with the number of births from the head. The average number of children living in the household increases by less than one with an additional birth. Couples that have fewer children are in particular (i) more likely to

\footnotetext{
${ }^{4}$ The results are robust to the use of the number children still alive at the time of the survey.
} 
live with their parents, nephew and nieces, or other non-relatives; they are (ii) less likely to live with their spouse, grand-children, or children-in-law.

The relative complexity of a household's structure implies that children and spouses are not the only variables determining the household size. Whether non-nuclear members are complements or substitutes to children is an empirical question. If, in the short-run, an additional birth mechanically increases the number of children, it might also affect the arrival or departure of nonnuclear members, like parents and siblings of the head. Later on, it is not clear whether having more children induces the earlier departure of children or more in-laws and grand-children within the household.

\section{Insert table 2 here}

\section{$3 \quad$ Empirical strategy}

In the estimation of the direct effect of births on household size, it is crucial to control for covariates which are correlated with the number of births and potentially affect household size. For instance, the age of the head is expected to affect the household size and is obviously correlated with the number of births. Table 2 provides descriptive statistics of the main variables of interests and of the main covariates on which we condition our estimations. A household head is, on average, 49 years old. The average age of mothers is 45. Eighty-eight percent of the heads are married, one percent are divorced or separated, and the rest have another civil status (mostly widows or never 
married). Nepali households are quite poor on average, with a thin asset ownership as well as low income and consumption expenditures. ${ }^{5}$ We also provide the share of the households living in the Terai or in the Hills. Less than nine percent of our sample comes from the Mountains. Note that all regressions include time and district fixed effects and therefore control for all variables that are constant at the district level and in a given survey year.

Despite the household level controls and district and time fixed-effects, there might be some unobserved characteristics that bias the estimation of the direct effect of the number of births on household size. If parents have a preference for large households, they will have more children and welcome additional external members in their household. It may be related to decreasing costs of raising a child in larger households, typically if parents of the head help in day care. This example implies upward biased estimates of the coefficient of interest. We therefore need an exogenous source of variation in fertility.

In an attempt to assess the causal impact of the number of children on the household size, we rely on the exogenous random variation of the firstborn gender combined with the preference for boys in Nepal. We use, as an instrument, a binary variable that is equal to one if the first-born child

\footnotetext{
${ }^{5}$ Consumption expenditures do include food monetary expenses, a valuation of home consumption, infrequent expenditures, health related expenses, and housing expenses (rent, water, electricity, garbage, communication, fuel). It does not include the purchase of productive inputs nor of durable assets. Income is the sum of all wage incomes from permanent and casual employment, income from self-employed activities, in agriculture or outside, including a market price valuation of home consumption, capital income, and transfers received.
} 
is a girl, and to zero otherwise. The effects of the first-born's gender have been analysed in various papers (Rosenzweig and Wolpin, 2000), in Asia (Chowdhury and Bairagi, 1990; Clark, 2000; Dreze and Murthi, 2001; Lee, 2008; Li and Wu, 2011; Milazzo, 2014b), and more recently, in Sub-Saharan Africa (Milazzo, 2014a). In Nepal, as in other countries, there is a strong preference for boys. Couples whose first child is a girl are more likely to have another child, hoping it will be a boy (Gudbrandsen, 2013; Hatlebakk, 2012). In the next subsections, we first examine the strength of the instrument before discussing its relevance to our problem.

\subsection{Preference for boys and strength of the instrument}

In Nepal, using the sex of the first-born as an instrumental variable has both statistical relevance and anthropological soundness. On average, at the time of the survey, the couples had 4.53 children: 4.78 if they first had a girl, and 4.3 if they first had a boy. The median number of children is 5 among the families with a first-born girl and 4 among the families with a first-born boy. Figure 3 shows that there is first order stochastic dominance of the number of births distribution in first-born girl families over first-born boy families. ${ }^{6}$ This is in line with our expectations that people keep having children as long as they do not reach the desired number of boys.

Insert figure 3 here

\footnotetext{
${ }^{6}$ This is confirmed by a two-sample Wilcoxon rank-sum test, which rejects the equality of distributions with an associated p-value $<0.0001$.
} 
Onesto (2005) summarizes the preference for boys by quoting a Nepali saying: "To get a girl is like watering a neighbor's tree. You have the trouble and expense of nurturing the plant but the fruits are taken by somebody else." A daughter "is useful and valuable in her childhood years when she can do chores and serve the household". Afterwards, she marries, and all long-term investment benefits flow to her husband. In a more in-depth study of a Tamang community, Fricke (1986) reports that there is a slightly greater desire for male children, but that babies are equally treated. Women provide labour force as long as they are members of the household and form a corner-stone of extended reciprocity relationships. However, sons remain the only ones who formally inherit land and who take (financial) charge of their parents' funerals.

Nepalese have at least two good reasons to wish for at least two boys. As already mentioned, boys traditionally inherit the family's land. It becomes tradition to have a boy who will take care of the land and inherit the family's assets. In addition, it is easier for a boy to migrate. In the last couple of years, the returns to migration are very high, and remittances constitute a very important part of household's revenues (CBS, 2011). Families also report wanting a second boy to get an education while the first takes care of the land. Additionally, it is a son who is supposed to light the parents' funeral pyre. 


\subsection{Validity of the instrument}

The validity of our strategy crucially relies on the randomness of the firstborn's gender. Such will not be the case if parents can choose the sex of their children. Sex-selective abortion is a long and lasting phenomenon in China (Chen et al., 2013), Taiwan (Lin et al., 2014), or India (Nandi and Deolalikar, 2013), and, in recent years, an emerging concern in Nepal (Lamichhane et al., 2011; Subedi, 2011). In Nepal, an increase in sex-selective abortion could have happened after 2002/4 when abortion was legalized and the government began to provide Comprehensive Abortion Care services at lower prices. This, however, does not appear to be the case (at parity one, at least). Using several rounds of DHS data, Frost et al. (2013) find no evidence of sex selective abortion prior to 2002, except maybe at the border with India. More importantly, they find no evidence of sex selective abortion among the first-born even after the legalization. A second, more recent, source of evidence is Valente (2014). She uses data from the same age group of mothers, and compares siblings before and after the opening of an abortion center nearby. She concludes that there is no support for the hypothesis that legal abortion centers in Nepal have led to more sex-selective terminations. ${ }^{7}$

On top of the randomness and conditional on the covariates that we include, the gender of the first-born cannot have a direct effect on a household's size. But its effect must go through the number of additional children. Such

\footnotetext{
${ }^{7}$ Note that our results are robust to excluding the last round of data and using only data prior to the legalization of abortion.
} 
will not be the case if, for instance, (i) the gender of the first-born affects the reporting of the number of children ever born by their mother; (ii) if the gender of the first-born affects the dynamics of household creation (e.g. if a first-born boy becomes the household head); or (iii) if the parents adopt dif-

ferent behaviours (related to income and the size of their household) because their first-born is a boy rather than a girl. We discuss these issues in section 6 , after the presentation of the results.

One downside of this instrumental variable is that it can only be used on the sub-set of households who have had at least one child. This limits its external validity, and the results cannot be used to assess the effects of having one child versus not having any children.

\section{Number of children and household size}

We first look at the relation between the total number of children and household size. We show that a larger number of births increases the household size when mothers are below 40. The opposite pattern is observed for mothers above 40 who have thus completed their fertility. In this group, the household size is negatively related to the number of births. We observe that old households who have had more children host less non-nuclear relatives and more nuclear relatives. The net effect is negative and statistically different from zero. As we explained above, for both groups, we use the gender of the 
first-born child as an instrument for the total number of children. ${ }^{8}$

We estimate equation (1), where the dependent variable $y_{i t w}$ has a value for each household $i$ at time $t$ in district $w$ and is given by: the number of household members ; the number of nuclear members; the number of extended family members ; the number of members older than 16; and the number of members younger than 16 . Our main variable of interest is $K_{i t w}$, the number of children of the household's head. $\mathbf{X}$ is a vector of control variables presented in Table 2 with associated parameter vector $\boldsymbol{\Phi}$. Regressions also include district and time fixed effects. ${ }^{9}$

$$
y_{i t w}=\beta_{1} K_{i t w}+\mathbf{X}_{\mathbf{i t w}} \mathbf{\Phi}+\alpha_{w}+\delta_{t}+\varepsilon_{i t w}
$$

\subsection{The gender of the first-born instruments the num- ber of children}

In Table 3 and 5, we estimate the effect of one additional child on the household structure. We use five dependent variables: (i) the size of the household, equal to the number of household members; (ii) the number of nuclear members, where we only count the head, his spouse(s), and their children; (iii) the number of other members, that is, the household size minus the number of nuclear members; (iv) the number of members older than sixteen and; (v)

\footnotetext{
${ }^{8}$ The division of the sample in two groups of mothers simplifies the discussion. The conclusions are robust if the variable of interest is the interaction between the mother's age and the number of children.

${ }^{9}$ All our regressions with instruments are estimated using ivreg2, developed in Baum et al. (2007).
} 
the number of members younger than sixteen. We first present ordinary least squares regressions, and then two stage least square regressions.

We control for some household characteristics that may also affect the household structure as well as for productive assets owned by the households. Household characteristics are head's gender, ethnicity dummies, as well as head's age. Productive assets include the amount of land and the number of cows owned, the average education level among the adults of the household, and a binary variable equal to one if the household owns a non-agricultural business. All regressions also include time and district fixed effects. The results hold without those controls. They are also robust to the inclusion of the age of the first-born among the controls.

Table 3 presents the results for mothers below 40. An additional birth increases the number of household members by 0.6 (first specification) to 0.7 (specification (7)). These new members are children of the head. Notice that the instrumentation does not affect estimations to a large extent.

Insert table 3 here

The pattern is different for older mothers who have completed their fertility. In Table 5, according to the 2SLS estimates (equation 7), having one more child decreases the household's size by 0.6 members. The positive effect $(+0.35)$ of the additional child on the number of nuclear members (equation $8)$ is more than compensated by the decrease (-0.92) in other relatives hosted by the household (equation 9). 
As we emphasised in the introduction, the literature assumes a mechanical link between the number of children and the households' income per capita. By increasing the number of capita, but without contributing substantially to the income, additional children are expected to impoverish the households. If we do not discard this story and actually confirm it for young mothers, we have, however, shown that the effect is more subtle. Later in the mothers' life cycle, one additional child actually decreases the household size. The expected mechanism does not materialise anymore, because the arrival of new nuclear members in the household is more than compensated by a reduction in the number of other members.

Consequently, new births also affect the adult/children ratio in the household. As shown in Table 5, an additional birth does not change the number of children (below sixteen years old) in the household, but decreases the number of adults in the household. This change in the household composition is crucial to assessing the links between fertility and poverty. It is usually accepted that a child consumes less than an adult. And therefore, an additional birth could either increase or decrease the household's consumption per head, depending on the importance of the gains in consumption versus the potential loss in income. We turn to that question in the next section.

Insert table 5 here 


\section{Number of children and household consump- tion}

Policies aiming at reducing fertility implicitly assume that additional births decrease household per capita income. Indeed, if additional children do not contribute substantively to the household's income, but increase the number

of people in the household, they must decrease the per capita income and consumption. We estimate the correlation between the number of children and the household's consumption.

Our regressions are similar to those presented in the previous section, and we use the same instrument. We test the correlation between the household's consumption per capita and the number of children in Tables 4 and 6 . The first column shows an OLS regression, and the first and second stages of the 2SLS estimation is in the next two columns. The contrast between young and old mothers mirrors the discussion on household composition. For young mothers, there is no doubt that an increase in the number of children is associated with lower consumption per capita, even when adjusting household size using equivalence scale. Our analysis suggests that the story may be more optimistic for older mothers. As expected from our results about the evolution of the household size, the coefficient of "births" is smaller in absolute value than for young mothers. In the OLS specification, it is still negative but closer to 0 . When instrumenting, point estimates are very close to, and not significantly different from, zero. 
Note that we obtain similar results if we use the household income instead of its consumption. The results are also similar when we use the OECD modified scale to adjust the household size to take into account changes in the composition of the household (more children and less adults). ${ }^{10}$

Insert table 4 here

Insert table 6 here

\section{Discussion}

In this section, we discuss the mechanisms that could explain our results. We use additional statistics and robustness checks to consolidate our interpretation.

Our findings are consistent with incentives for children to stay with, or depart from, their parents according to the Nepali succession law. Successions in Nepal are organized around two regimes: partition and inheritance. ${ }^{11}$ The most common regime is partition, a regime under which all members of the family are joint owners of the family property. While partitioning the property, it is divided between the father, the mother, and the sons. A share is also left aside to cover marriage expenses of daughters and their dowries. As long as household members live together, i.e. until partition, all property collected by any individual from agriculture, industry, business, etc. is

\footnotetext{
${ }^{10}$ The $O E C D$ - modified scale assigns a value of 1 to the household head, of 0.5 to each additional adult member, and of 0.3 to each child.

${ }^{11}$ See Nepal's Muluki Ain, The General Code.
} 
pooled between all those living together. Property earned by an individual through his/her knowledge, skill, and effort, or given to him/her through donation remains individual property. Notice that the partitioning can take place before the death of the father, typically at the departure of children. Once someone has taken his share and therefore has left the household, (s)he is no longer entitled to inheritance, provided some brothers or unmarried sisters jointly live with their parents until their death (Fezas, 1986).

In small sibships, under the partition regime, children have relatively larger incentives to stay with their parents. Indeed, staying is relatively more profitable and less costly as the number of siblings goes down. In a context where income is pooled, a smaller number of siblings reduces the moral hazard in team among potential contributors to household wealth. On the benefits side, the parents' partition share is relatively larger in households with fewer children. There is therefore more to receive later on when wealth is transmitted through inheritance at the death of parents than by leaving early and relying on the partition share. In larger families, incentives go in the opposite direction. Children's contributions to household wealth are diluted among many potential claimants, and the two parents' share is smaller and would anyway be divided between many household members after the parents' death.

To summarize, partition grants at most $\frac{1}{N+2}$ of household wealth to a child leaving, with $N$ being the number of children. On the other side, inheritance transfers at least $\frac{1}{N}$ of this wealth to a child who remains with 
one's parents until their death. The difference between the two regimes, $\frac{1}{N}-\frac{1}{N+2}$, decreases in the number of children. Combined with the reduction of the relative costs of leaving early, the dual succession system can explain a negative relationship between the number of children and the household size when children reach the age of asking their share and creating their own separate household.

The Nepalese partition system shares similarities with other inheritance patterns in the world. In the typology of Todd (2011), the family system described in the Muluki Ain is close to the "stem-family". ${ }^{12}$ According to Todd, such is the case of around $10 \%$ of family systems in Eurasia, with, for example, the Sikh areas, Sweden, Norway, Ireland, some parts of Germany, or the southeast of France. The Nepalese system has, however some distinctive features, notably because it departs from impartible inheritance. ${ }^{13}$ This is a system of unigeniture with pre-mortem compensating payment. This is observed, for instance, among herders of south Bostwana, where the father earmarks cattle and sets land aside at the establishment of a son's own household (Peters, 1994). Augustins (1989) extensively describes a second example. He explains how wealth is transmitted in the French Pyrenees before the French revolution and the adoption of the civil law. Brothers and sisters of the chosen heir have to leave their parents' house. Sisters leave with a dowry and brothers are entitled to "la Légitime".

\footnotetext{
${ }^{12}$ First described in french as "Famille Souche".

${ }^{13}$ See Platteau and Baland (2001) for a deep discussion of impartible inheritance vs. equal division) and their consequences on intra-family relationship.
} 
The argument of inheritance can hardly be separated from land ownership and use. In rural Nepal, land is the main production asset and is labour intensive. The land market is also very limited, and according to the NLSS data, very few transactions occur. Households may therefore have to adapt their size to the amount of land that they own. In this case, land owners with few children would be much more likely than landless households to host other relatives working on the land. We therefore expect the effects of the number of children on the household size to be stronger among land owners than among landless households. To test this mechanism, we run our main regressions on the sub-sample of landless households and of land owners. The results are displayed in Table A.2. We find that the results are indeed stronger among the land owners. Among landless households, the negative effect of the number of children on the household's size is greatly reduced and loses significance.

The differences between land owners and landless households are consistent with both explanations: the effects of the partition and inheritance regime, and the optimization of the number of household members per unit of land. The data about land holdings and acquisitions are, however, too limited in the NLSS to allow for a deeper investigation.

If the partition regime, and the use of land, are important mechanisms in explaining household structure, other mechanisms could theoretically explain our findings. In the remaining part of this section, we discuss them and show that they do not hold empirically. 
First, our estimates might be biased if parents systematically forget to report children who have left the household. It looks a priori as a benign measurement error problem, which would reduce the absolute value of the coefficients of interest. It could, however, be more serious in our context. Parents could have a higher propensity to report their sons than their daughters, since the latter have higher probabilities to leave the household when they marry. It implies that we would observe fewer first-born girls. Firstborn boys would be more numerous and statistically associated with smaller observed offspring because some of their sisters would have left the household and would end up being unreported. This would typically inflate the strength of our instrument and eventually associate households with few children together with more non-nuclear members, namely daughters-in-law and grandchildren. The data, however, discard this channel. The sex ratio at birth is stable across birth ranks, does not systematically differ from a ratio of 108 boys for 100 girls, and is not statistically different between two consecutive birth ranks. The stability of the sex ratio by birth rank remains if we focus on specific mothers' age group and is not affected either if we control for child age. The level of the sex ratio is also consistent with medical wisdom. Its steadiness over birth rank by mother age groups, controlling for the time since child birth, discards large biases arising from potential sex-selective recall or recall driven by the presence within the household.

Second, the devolution of headship at the arrival of the first-born boy could have been an issue. Under this mechanism, the birth of a boy would 
transform the head and spouse in parents, the father into a head, former head's children into siblings of the new head, the mother into head's spouse,... The birth of a girl would only add a grand-daughter in the household while leaving the rest of household structure unchanged. We do not, however, find any significant relationship between the sex of the first born and the age of the head nor with the age of the head's spouse.

Third, it could be argued that the first boy, who is the heir, is specific, and that his gender could play a direct role on how the parents compose their household. To check that our results are not driven by the order of the gender-birth sequence, we provide additional tables where we repeat the same analysis but use the gender of the second child as an instrument for the number of consecutive births. In Table A.3 of the Appendix, we only consider heads who have at least 2 children. We control for the gender of the first child. We instrument the number of additional children by the gender of the second child. This process allows us to check that the results are not driven directly by the gender of the first child by relaxing the exclusion restriction on the first-born. This strategy also allow us to control for the gender composition among older siblings, and for the birth spacing between the first and the second born. The results are consistent with our previous findings.

Fourth, a weakness of the data is the absence of old mothers (over 49 years old). Any conclusion related to this group is hazardous, since it only relies on "out-of-sample" prediction. However, if the mechanisms we push 
forward and the trend we observe before 50 years of age stabilizes or even continues, then the average household size could decrease even more with additional children if we had been able to estimate the relationship on all mothers who have completed their fertility.

Fifth, a direct effect of the gender of the children on the household size could be a concern: if, for instance, girls are more likely to leave the household while boys are more likely to stay. In this scenario, the instrument would not be valid if the gender of the first-born determines the global proportion of girls and boys among the household's children, and if that proportion has an effect on the household size, independently from the total number of children. In Table A.4, we estimate the correlation between the household size and the number of girls among the children born for the sample of mothers who have completed their fertility. We do this for each sub-sample of households that have the same number of children: Column 1 includes all households that have only 1 child; column two: two children; column 3: three children; and so on.

We find that there is no clear relationship between the household size and the gender composition of the children. Among those who have only one child, whether the child is a boy or a girl is not correlated with the household size. Among those who have two children, having one daughter and one son, compared to having two sons, is negatively correlated with the household size. But having two daughters instead of two sons is not correlated with the household size. Among families with three or four children, having more 
girls is associated with smaller households, but among families with six or more children, having more girls is associated with larger households. More importantly, the gender of the first-born is not significantly correlated with the gender of the following children. These findings support the validity of the instrument, as it suggests that the household size is not directly dependent on the number of girls and boys among the children.

Finally, there is an important literature on child fostering. ${ }^{14}$ The phenomenon is relatively well documented in Africa (see, for example, Ainsworth (1996) about Côte d'Ivoire, Akresh (2009) about Burkina Faso, Alber (2004) about Benin, Beck et al. (2015) about Senegal, Bledsoe (1990) about Sierra Leone, Castle (1995) about Mali, or Verhoef and Morelli (2007) about Cameroon). The focus of this literature has been on the consequences of fostering on children's welfare, rather than on the identification of the determinants of fostering. Nonetheless, fostering is generally linked to the potential for children's education (they are fostered closer to schools), to shocks (such as the parents' migration), or the need for domestic work. In Senegal, Beck et al. (2015) also show that fostering is strongly correlated with the household size (the number of members before fostering). Larger households in particular are significantly more likely to send out children. There is much less research on the topic in Asia (one exception is Marazyan (2011) about Indonesia) and we are not aware of any quantitative research on child fostering in Nepal. The

\footnotetext{
${ }^{14}$ We follow the terminology of the Demographic Health Surveys and define a fostered child as a child below eighteen years old living in a household that does not include his parents.
} 
phenomenon exists in Nepal: according to the Nepal DHS 2011, around 11\% of households foster a child (the number is slightly lower in the three rounds of NLSS data). It is therefore legitimate to wonder whether our results can be explained by a fostering mechanism, where the larger households would foster out more children, while the smaller households would foster in more children.

To test this mechanism, we estimate the correlation between the number of children and the number of fostered children. One weakness of the NLSS data is that we can only identify the children fostered in, but not those fostered out. We do not find any correlation between the number of children born and the number of other children fostered in, neither in the OLS estimation nor in the IV. The estimates are displayed in the Appendix, Table 5. Furthermore, as we have shown in Table 5, the reduction in household size observed among old households who had more children comes from hosting a lower number of adult member, not from hosting a different number of members below eighteen. We therefore have no evidence that effects observed on the household size and composition happen through child fostering.

We end this discussion with two final remarks.

Our instrumental variable approach also shows that additional children increase the number of nuclear members but decrease the number of nonnuclear members among "old" mothers. This is especially true when the head's children become older, leading to their departure and to the absence of the head's daughters-in-law and grandchildren in large sibships. The di- 
rection of the OLS bias with respect to IV estimates indicates a positive reverse causality between household size and the number of children. This can be explained by a preference for large households in households with more members or by economies of scale in larger households that decrease the cost of raising additional children.

Finally, we want to repeat that our main result is observed for mothers who have completed childbearing (identified as older than forty years old). For younger mothers, as explained above, we find that having additional children increases the household size and decreases the household's per capita consumption. Our claim that, on average, additional children decrease the household size and leave the household's per capita consumption unchanged is only true later in the life cycle, when mothers have reached forty years of age. This is not true in the short term.

\section{Conclusion}

Analysing data from around eight thousand households surveyed in the Nepal Living Standard Surveys, we find that a couple's number of children affects its household's size in an unexpected manner: once fertility is completed, for women aged 40 to 50 and eventually later on, household size decreases with additional births. Nepalese households are embedded into larger social networks, and those households with fewer children tend to host more other people. The regressions paint a very clear picture: an additional child in- 
creases the number of nuclear family members but decreases the number of other adult hosts.

This finding is consistent with two potential mechanisms: (i) the succession system of Nepal which combines a partition regime and inheritance; and (ii) an argument related to the equalisation of labour per land units. Richer data, combining this approach with precise information on the history of household level shocks, would allow to precisely separate the extensive from the intensive margin in the relation.

We also discuss correlations between the number of children of a couple and their household's per capita consumption. This correlation is very consistent with the effects on the household's size: on average, there is no significant correlation between the number of births and the household's per capita consumption for mothers with completed fertility. For younger mothers, the relation behaves as expected, with a reduction of consumption per capita as the number of births increases.

To limit endogeneity biases, we have used the gender of the first-born child as an instrument for the total number of children. The main threat to the instrument's validity is the possibility of sex-selective abortion; the literature on this topic, however, shows that sex-selective abortion of the first born was not an issue in Nepal at the times under study.

This result has important implications. In particular, it emphasizes the role of family networks and hosting in modulating the household's response to new births. These dynamics should be taken into account in population 
control policies. Our study shows that having less children means that parents can expect to host more relatives, and more adults in the longer run. If hosting relatives is the best old age support that parents can hope for, then the quantity of children is, on average, not the best old age insurance.

The argument relies on uncoordinated and independent fertility decisions between households. If all households have fewer children, a general tendency in Nepal over the last two decades, the mechanism we put forward tends to increase the size of households, and therefore reduces the increase in the number of households for a given population size. It goes against the conventional wisdom depicted, for instance, in Figure 1. This difference may actually have important consequences in terms of poverty and environmental impact. First, we show that it is not reasonable to expect a surge in consumption per capita in households with fewer children, at least once mothers have completed their fertility. Second, numerous goods are public at the household level, from primary consumption goods such as a common roof or heating, to more complex products such as insurance arrangements. They benefit more members in larger households and do increase the average consumption per capita in a way that is hard to measure. Third, the complexity of the household structure raises more specifically the question of the income and consumption distribution between household members. Fourth, public bads and pollution are prominent at the household rather than individual level. As Axinn and Ghimire (2011) argue, households rather than people determine, for instance, land use and deforestation. The relative reduction 
in the number of households associated with lower fertility may actually induce a positive feedback loop on household opportunities. These important questions could not be answered here and are left to future research. 


\section{References}

Ainsworth, M. (1996). Economic aspects of child fostering in Côte d'Ivoire. Research in Population Economics, 8:25-62.

Akresh, R. (2009). Flexibility of household structure: Child fostering decisions in Burkina Faso. Journal of Human Resources, 44(4):976-997.

Alber, E. (2004). Grandparents as foster-parents : transformation in foster relations between grandparents and grandchildren in northern Benin. Africa: Journal of the International African Institute, 74(1):28-46.

Angrist, J., Lavy, V., and Schlosser, A. (2010). Multiple experiments for the causal link between the quantity and quality of children. Journal of Labor Economics, 28(4):773-824.

Augustins, G. (1989). Comment se perpétuer? Devenir des lignées et destins des patrimoines dans les paysanneries européennes. Société d'ethnologie.

Axinn, W. G. and Ghimire, D. J. (2011). Social organization, population, and land use. American Journal of Sociology, 117(1):209-258.

Baum, C., Schaffer, M., and Stillman, S. (2007). ivreg2: Stata module for extended instrumental variables/2SLS, GMM and AC/HAC, LIML, and k-class regression. Boston College Department of Economics, Statistical Software Components S425401. 
Beck, S., Vreyer, P. D., Lambert, S., Marazyan, K., and Safir, A. (2015). Child fostering in Senegal. Journal of Comparative Family Studies, 46(1):57-73.

Becker, G. S., Duesenberry, J. S., and Okun, B. (1960). An economic analysis of fertility. In Demographic and Economic Change in Developed Countries, pages 225-256. Columbia University Press.

Black, S. E., Devereux, P. J., and Salvanes, K. G. (2005). The more the merrier? the effect of family size and birth order on children's education. The Quarterly Journal of Economics, 120(2):669-700.

Bledsoe, C. (1990). 'no success without struggle': Social mobility and hardship for foster children in Sierra Leone. Man, 25(1):70-88.

Castle, S. E. (1995). Child fostering and children's nutritional outcomes in rural Mali: The role of female status in directing child transfers. Social Science 83 Medicine, 40(5):679 - 693.

CBS. Technical report.

CBS (2011). Nepal Living Standards Survey Household 2010-2011. Statistical Report Vol. 2, Nepal Central Bureau of Statistics.

Chen, Y., Li, H., and Meng, L. (2013). Prenatal sex selection and missing girls in China: Evidence from the diffusion of diagnostic ultrasound. Journal of Human Resources, 48(1):36-70. 
Childs, G. (2001). Demographic dimensions of an intervillage land dispute in Nubri, Nepal. American Anthropologist, 103(4):1096-1113.

Chowdhury, M. K. and Bairagi, R. (1990). Son preference and fertility in Bangladesh. Population and Development Review, 16(4):749-757.

Clark, S. (2000). Son preference and sex composition of children: Evidence from India. Demography, 37(1):95-108.

Cox, D., Fafchamps, M., Schultz, T. P., and Strauss, J. A. (2007). Chapter 58 extended family and kinship networks: Economic insights and evolutionary directions. In Handbook of Development Economics, volume 4, pages 37113784. Elsevier.

Dreze, J. and Murthi, M. (2001). Fertility, education, and development: Evidence from India. Population and Development Review, 27(1):33-63.

Fezas, J. (1986). Recent Research in Nepal, chapter The Nepalese law of succession, pages 159-186. Munchen: Weltforum.

Fricke, T. E. (1986). Himalayan households: Tamang demography and domestic processes. UMI Research Press.

Frost, M. D., Puri, M., and Hinde, P. R. A. (2013). Falling sex ratios and emerging evidence of sex-selective abortion in Nepal: evidence from nationally representative survey data. British Medical Journal Open, 3:doi: 10.1136/bmjopen-2013-002612. 
Gudbrandsen, N. H. (2013). Female autonomy and fertility in Nepal. South Asia Economic Journal, 14(1):157-173.

Hatlebakk, M. (2007). LSMS data quality in Maoist influenced areas of Nepal. CMI Working Paper WP 2007: 6.

Hatlebakk, M. (2012). Son-preference, number of children, education and occupational choice in rural Nepal. CMI Working Paper, 8.

Joshi, S. and Schultz, T. P. (2013). Family planning and women's and children's health: Long-term consequences of an outreach program in Matlab, Bangladesh. Demography, 50(1):149-180.

Kramer, K. L. (2010). Cooperative breeding and its significance to the demographic success of humans. Annual Review of Anthropology, 39(1):417-436.

Kremer, M. (1993). Population growth and technological change: One million B.C. to 1990. The Quarterly Journal of Economics, 108(3):681-716.

Lamichhane, P., Harken, T., Puri, M., Darney, P. D., Blum, M., Harper, C. C., and Henderson, J. T. (2011). Sex-selective abortion in Nepal: a qualitative study of health workers' perspectives. Womens Health Issues, 21(3):37-41.

Lee, J. (2008). Sibling size and investment in children's education: An Asian instrument. Journal of Population Economics, 21(4):855-875. 
Li, L. and Wu, X. (2011). Gender of children, bargaining power, and intrahousehold resource allocation in China. The Journal of Human Resources, 46(2):295-316.

Lin, M.-J., Liu, J.-T., and Qian, N. (2014). More missing women, fewer dying girls: The impact of sex-selective abortion on sex at birth and relative female mortality in Taiwan. Journal of the European Economic Association, 12(4):899-926.

Malthus, T. R. (1798). An Essay on the Principle of Population, as it affects the future Improvement of Society, with Remarks on the Speculations of Mr. Godwin, M. Condorcet, and Other Writers. J. Johnson, London, 1st edition.

Marazyan, K. (2011). Effects of a sibship extension to foster children on children's school enrolment: A sibling rivalry analysis for Indonesia. The Journal of Development Studies, 47(3):497-518.

Milazzo, A. (2014a). Son preference, fertility and family structure : evidence from reproductive behavior among Nigerian women. Policy Research Working Paper Series 6869, The World Bank.

Milazzo, A. (2014b). Why are adult women missing ? son preference and maternal survival in India. Policy Research Working Paper Series 6802, The World Bank. 
Nandi, A. and Deolalikar, A. B. (2013). Does a legal ban on sex-selective abortions improve child sex ratios? evidence from a policy change in India. Journal of Development Economics, 103(0):216 - 228.

Onesto, L. (2005). Dispatches from the People's War in Nepal. Pluto P.

Peters, P. (1994). Dividing the Commons-Politics, Policy and Culture in Botswana. University Press of Virginia.

Platteau, J.-P. and Baland, J.-M. (2001). Access to land, rural poverty and public action, chapter Impartible Inheritance versus Equal Division: a comparative perspective centered on Europe and Sub-Saharan Africa, pages 27-67. Oxford University Press.

Rosenzweig, M. R. and Wolpin, K. I. (2000). Natural "Natural experiments" in economics. Journal of Economic Literature, 38(4):827-874.

Samuelson, P. A. (1958). An exact consumption-loan model of interest with or without the social contrivance of money. Journal of Political Economy, 66:467.

Schultz, T. P. and Strauss, J. A. (2007). Chapter 52 population policies, fertility, women's human capital, and child quality. In Handbook of Development Economics, volume 4, pages 3249-3303. Elsevier.

Subedi, D. (2011). Missing girls in Nepal: An emerging challenge. Health Prospect, 10:34-36. 
Todd, E. (2011). L'origine des systèmes familiaux: L'Eurasie. Gallimard.

Valente, C. (2014). Access to abortion, investments in neonatal health, and sex-selection: Evidence from Nepal. Journal of Development Economics, 107:225-243.

Verhoef, H. and Morelli, G. (2007). "A child is a child": Fostering experiences in northwestern Cameroon. Ethos, 35(1):33-64. 


\section{Figures and tables}

Figure 1: A 1992 poster from the India Ministry of Health and Family Welfare

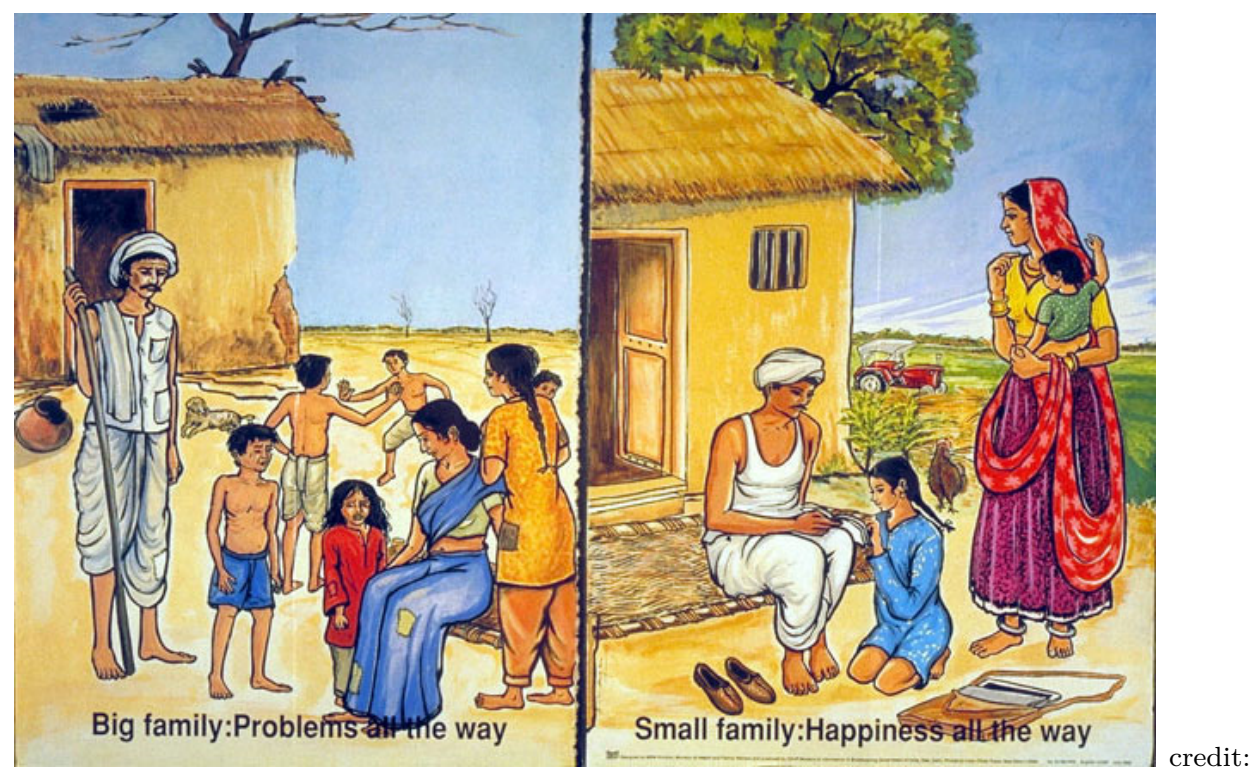

courtesy of the Media/Materials Clearinghouse at the Johns Hopkins University, Bloomberg School of Public Health, Center for Communication Programs. 
Figure 2: Number of children and incomes in the household

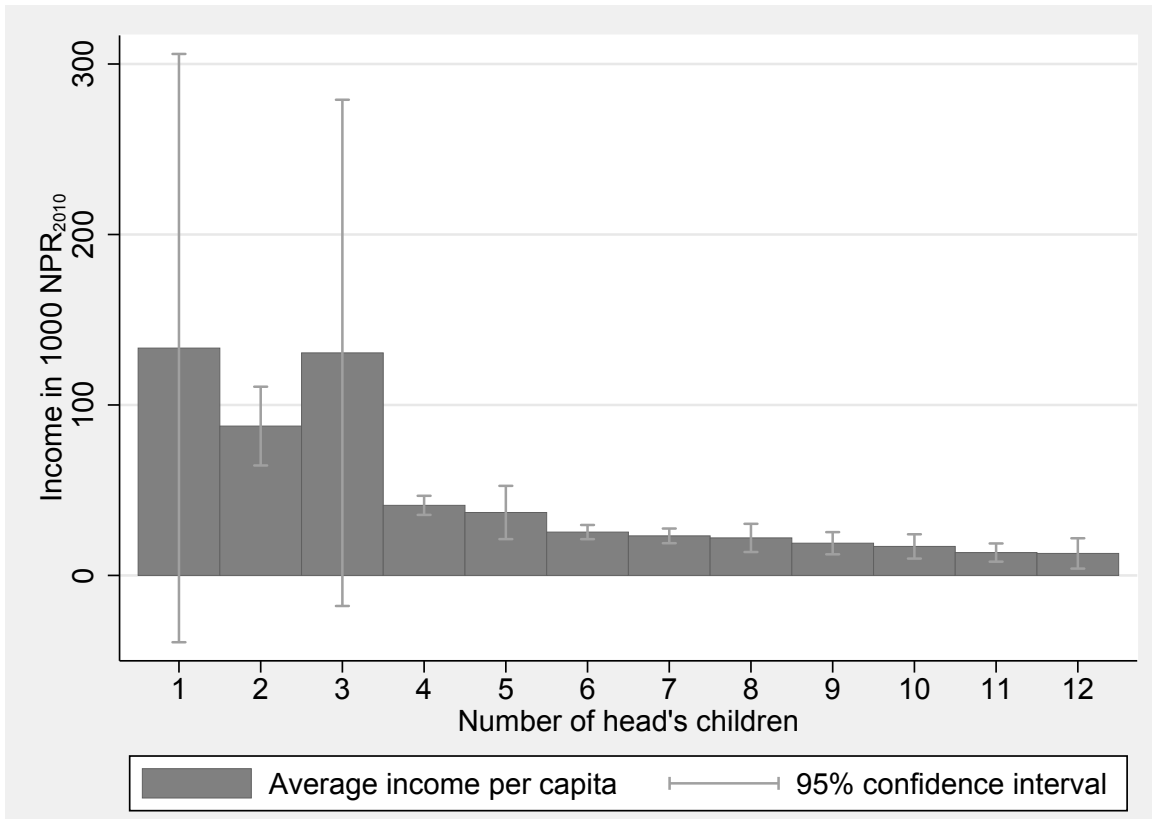


Figure 3: Distribution of households by number of births and gender of the first-born

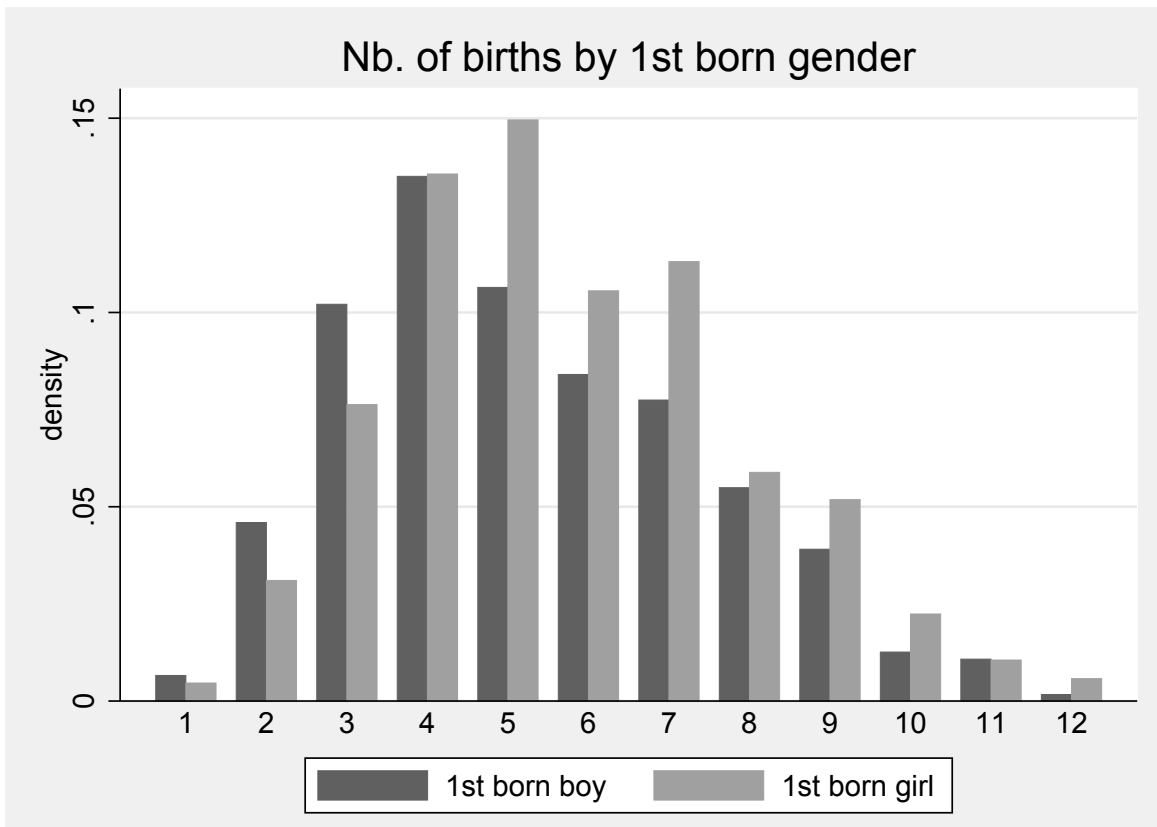


Table 1: Number of children, household size, and income per capita

\begin{tabular}{|c|c|c|c|c|c|c|c|c|}
\hline \multirow{4}{*}{$\begin{array}{l}\text { Variable } \\
\text { Head's number of children }\end{array}$} & Survey & Mean & & Std. Dev. & Median & $25 \%<$ & $25 \%>$ & Observations \\
\hline & $\mathrm{T} 1$ & 5.30 & \multirow{3}{*}{$\begin{array}{l}* * * \\
* * *\end{array}$} & 2.22 & 5 & 4 & 7 & 454 \\
\hline & $\mathrm{T} 2$ & 4.71 & & 2.16 & 4 & 3 & 6 & 665 \\
\hline & T3 & 4.06 & & 1.84 & 4 & 3 & 5 & 1004 \\
\hline \multirow[t]{3}{*}{ Household size } & $\mathrm{T} 1$ & 6.13 & \multirow{3}{*}{$\begin{array}{l}* * * \\
* * *\end{array}$} & 2.72 & 6 & 4 & 7 & 454 \\
\hline & $\mathrm{T} 2$ & 5.66 & & 2.51 & 5 & 4 & 7 & 665 \\
\hline & T3 & 5.01 & & 2.14 & 5 & 3.5 & 6 & 1004 \\
\hline \multirow{3}{*}{ 壳 } & $\mathrm{T} 1$ & 23093 & \multirow[b]{3}{*}{$*$} & 34607 & 14663 & 10008 & 23726 & 453 \\
\hline & $\mathrm{T} 2$ & 42677 & & 264624 & 20339 & 12573 & 34227 & 665 \\
\hline & T3 & 90913 & & 964100 & 30389 & 18153 & 59064 & 998 \\
\hline Income & $\mathrm{T} 1$ & 129835 & & 178168 & 85644 & 53846 & 143022 & 453 \\
\hline (NPR 2010) & $\mathrm{T} 2$ & 201781 & & 1058708 & 102213 & 66637 & 177535 & 665 \\
\hline & T3 & 436002 & & 5748472 & 145296 & 86865 & 257368 & 998 \\
\hline
\end{tabular}


Table 2: Summary statistics of the main covariates

\begin{tabular}{lccccc}
\hline \hline \multicolumn{1}{c}{ Variable } & Mean & Std. Dev. & Min. & Max. & N \\
\hline Hh. size & 5.45 & 2.44 & 1 & 26 & 2123 \\
Children & 4.53 & 2.09 & 1 & 12 & 2123 \\
Married & 0.88 & 0.33 & 0 & 1 & 2123 \\
Divorced or separated & 0.01 & 0.12 & 0 & 1 & 2123 \\
Other civil status & 0.11 & 0.31 & 0 & 1 & 2123 \\
Hh. income (1000NPR) & 296.85 & 3994.23 & 0.24 & 181275 & 2116 \\
Frequent consumption (1000NPR) & 124 & 83 & 5 & 1271 & 2123 \\
Male head & 0.8 & 0.4 & 0 & 1 & 2123 \\
Age of head & 48.72 & 5.57 & 26 & 80 & 2123 \\
Mother's age & 44.69 & 2.4 & 41 & 49 & 2123 \\
Number of spouses & 0.8 & 0.4 & 0 & 1 & 2123 \\
Land owned (Ha.) & 0.61 & 1.01 & 0 & 13.54 & 2123 \\
Cows owned & 2.45 & 2.81 & 0 & 22 & 2123 \\
Avg. education & 4.27 & 3.57 & 0 & 16 & 2123 \\
Non-farm business & 0.35 & 0.48 & 0 & 1 & 2123 \\
Rural & 0.68 & 0.47 & 0 & 1 & 2123 \\
Hills & 0.51 & 0.5 & 0 & 1 & 2123 \\
Terai & 0.41 & 0.49 & 0 & 1 & 2123 \\
Survey 2 & 0.31 & 0.46 & 0 & 1 & 2123 \\
Survey 3 & 0.47 & 0.5 & 0 & 1 & 2123 \\
\hline
\end{tabular}


Table 3: The number of children and the composition of the households - young mothers

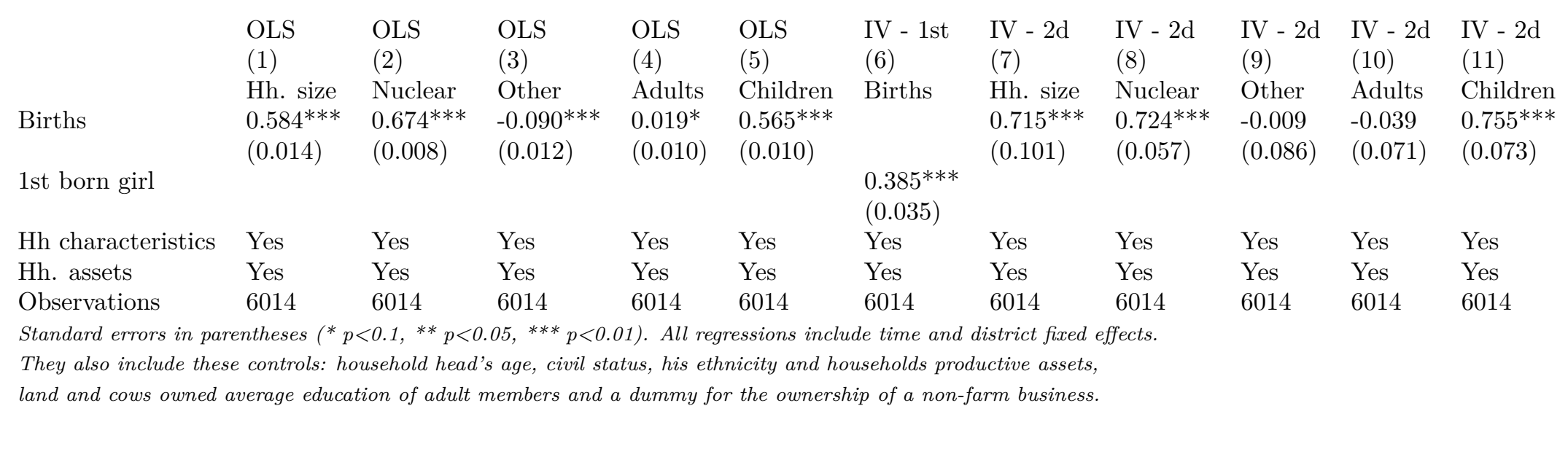


Table 4: The gender of the first-born and the household's consumption per capita - young mothers

$\begin{array}{llll} & \text { OLS } & \text { IV - 1st stage } & \text { IV - 2d stage } \\ & (1) & (2) & (3) \\ & \text { Cons./cap. (ln) } & \text { Births } & \begin{array}{l}\text { Cons./cap. (ln) } \\ \text { Births }\end{array} \\ & -0.074^{* * *} & & \left(0.136^{* * *}\right. \\ & (0.004) & & \\ \text { 1st born girl } & & 0.385^{* * *} & \\ & & (0.035) & \\ \text { Hh characteristics } & \text { Yes } & \text { Yes } & \text { Yes } \\ \text { Hh. assets } & \text { Yes } & \text { Yes } & \text { Yes } \\ \text { Observations } & 6014 & 6014 & 6014\end{array}$


Table 5: The number of children and the composition of the households - old mothers

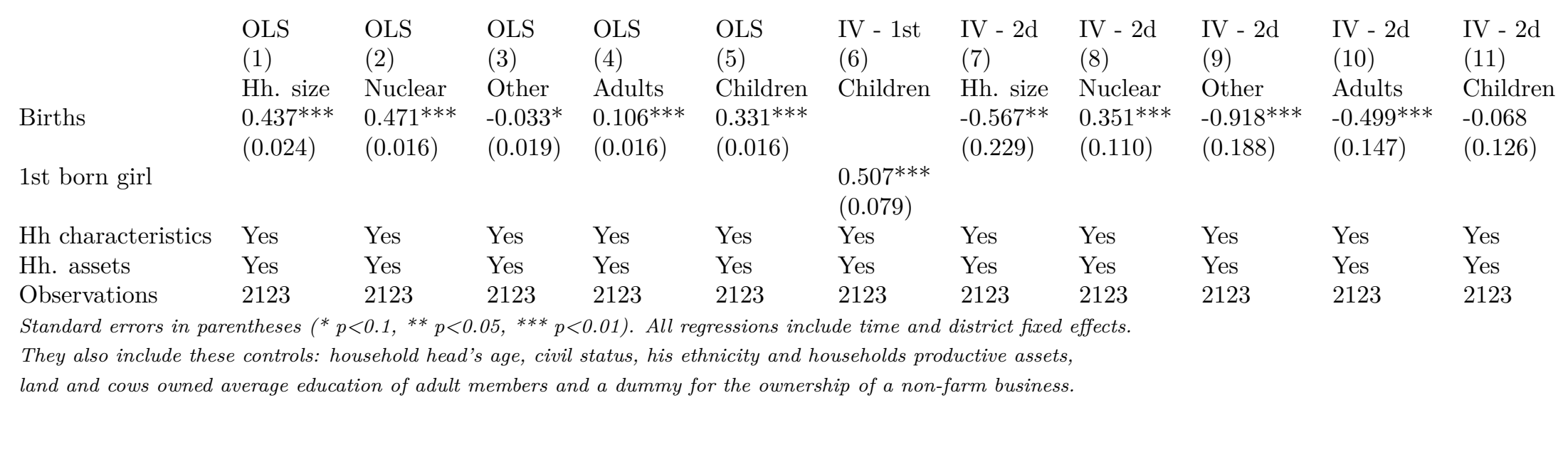


Table 6: The gender of the first-born and the household's consumption per capita - old mothers

\begin{tabular}{|c|c|c|c|}
\hline & OLS & IV - 1st stage & IV - 2d stage \\
\hline & Cons./cap. (ln) & Births & Cons./cap. (ln) \\
\hline Births & $\begin{array}{l}-0.054^{* * *} \\
(0.006)\end{array}$ & & $\begin{array}{l}-0.005 \\
(0.039)\end{array}$ \\
\hline 1st born girl & & $\begin{array}{l}0.507^{* * *} \\
(0.079)\end{array}$ & \\
\hline Hh characteristics & Yes & Yes & Yes \\
\hline Hh. assets & Yes & Yes & Yes \\
\hline Observations & 2123 & 2123 & 2123 \\
\hline
\end{tabular}

All regressions include time fixed effects. Hh. controls include the household head's age,

the head's ethnicity and households productive assets. Productive assets include land and cows owned, average education of adult members and a dummy for the ownership of a non-farm business. 


\section{A Appendix}

Table A.1: The number of births and the composition of the households

\begin{tabular}{|c|c|c|c|c|c|c|c|}
\hline \# Births & \# Households & Pr.(nuclear hh.) & Size of Hh. & Spouse & Child & Grand-child & \\
\hline$\overline{1}$ & $\overline{776}$ & 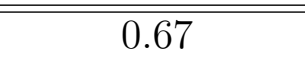 & 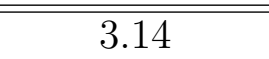 & 0.68 & 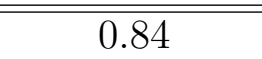 & 0.13 & \\
\hline 2 & 261 & 0.56 & 3.89 & 0.79 & 1.26 & 0.21 & \\
\hline 3 & 402 & 0.58 & 4.64 & 0.82 & 1.85 & 0.35 & \\
\hline 4 & 453 & 0.53 & 5.34 & 0.83 & 2.38 & 0.47 & \\
\hline 5 & 339 & 0.53 & 5.84 & 0.85 & 2.81 & 0.41 & \\
\hline 6 or more & 592 & 0.54 & 6.86 & 0.86 & 3.92 & 0.48 & \\
\hline All sample & 2123 & 0.55 & 5.45 & 0.83 & 2.58 & 0.40 & \\
\hline \# Births & Parents & Siblings & Nephew/niece & Child-in-law & Sibling-in-law & Parent-in-law & Others \\
\hline$\overline{\overline{1}}$ & 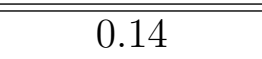 & 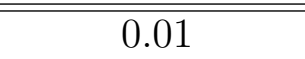 & 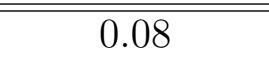 & 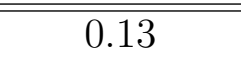 & 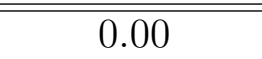 & 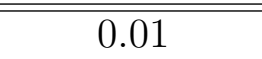 & $\overline{0.11}$ \\
\hline 2 & 0.11 & 0.05 & 0.06 & 0.19 & 0.03 & 0.03 & 0.16 \\
\hline 3 & 0.12 & 0.04 & 0.05 & 0.28 & 0.03 & 0.04 & 0.06 \\
\hline 4 & 0.12 & 0.02 & 0.03 & 0.38 & 0.01 & 0.03 & 0.06 \\
\hline 5 & 0.12 & 0.06 & 0.11 & 0.33 & 0.03 & 0.03 & 0.07 \\
\hline 6 or more & 0.09 & 0.03 & 0.03 & 0.41 & 0.01 & 0.01 & 0.03 \\
\hline All sample & 0.11 & 0.03 & 0.05 & 0.33 & 0.02 & 0.03 & 0.07 \\
\hline
\end{tabular}


Table A.2: The number of children and the composition of the households - Land owners and landless households

\begin{tabular}{|c|c|c|c|c|c|c|c|c|c|c|c|c|}
\hline & (1) & (2) & (3) & (4) & $(5)$ & (6) & (7) & $(8)$ & (9) & $(10)$ & (11) & (12) \\
\hline & Hh. size & Nuclear & Other & Adults & Children & Births & Births X landless & Hh. size & Nuclear & Other & Adults & Children \\
\hline Births & $0.447^{* * *}$ & $0.470^{* * *}$ & -0.022 & $0.094^{* * *}$ & $0.353^{* * *}$ & & & $-0.711^{* * *}$ & $0.353^{* * *}$ & $-1.064^{* * *}$ & $-0.553^{* * *}$ & -0.158 \\
\hline Births X landless & $\begin{array}{l}(0.026) \\
-0.052\end{array}$ & $(0.017)$ & $\begin{array}{l}(0.020) \\
-0.058\end{array}$ & $\begin{array}{l}(0.018) \\
0.066^{*}\end{array}$ & $\begin{array}{l}(0.017) \\
-0.118^{* * *}\end{array}$ & & & $\begin{array}{l}(0.271) \\
0.630\end{array}$ & $\begin{array}{l}(0.126) \\
-0.014\end{array}$ & $\begin{array}{l}(0.226) \\
0.644\end{array}$ & $\begin{array}{l}(0.170) \\
0.241\end{array}$ & $\begin{array}{l}(0.151) \\
0.390\end{array}$ \\
\hline 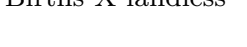 & $(0.054)$ & $(0.035)$ & $(0.041)$ & $(0.036)$ & $(0.035)$ & & & $(0.538)$ & $(0.249)$ & $(0.448)$ & $(0.337)$ & $(0.300)$ \\
\hline Landless & $\begin{array}{l}0.366 \\
(0.255)\end{array}$ & $\begin{array}{l}0.084 \\
(0.164)\end{array}$ & $\begin{array}{l}0.282 \\
(0.196)\end{array}$ & $\begin{array}{l}-0.241 \\
(0.171)\end{array}$ & $\begin{array}{l}0.607^{* * * *} \\
(0.166)\end{array}$ & $\begin{array}{c}-0.073 \\
(0.147)\end{array}$ & $\begin{array}{l}3.798^{* * *} \\
(0.072)\end{array}$ & $\begin{array}{l}-2.446 \\
(2.191)\end{array}$ & $\begin{array}{l}0.160 \\
(1.017)\end{array}$ & $\begin{array}{l}-2.606 \\
(1.825)\end{array}$ & $\begin{array}{l}-0.976 \\
(1.372)\end{array}$ & $\begin{array}{l}-1.470 \\
(1.223)\end{array}$ \\
\hline 1st born girl & & & & & & $\begin{array}{l}0.493^{* * *} \\
(0.092)\end{array}$ & $\begin{array}{l}-0.017 \\
(0.045)\end{array}$ & & & & & \\
\hline $\begin{array}{l}\text { 1st born girl } \\
\mathrm{X} \text { landless }\end{array}$ & & & & & & $\begin{array}{l}0.057 \\
(0.183)\end{array}$ & $\begin{array}{l}0.527^{* * *} \\
(0.089)\end{array}$ & & & & & \\
\hline Hh characteristics & Yes & Yes & Yes & Yes & Yes & Yes & Yes & Yes & Yes & Yes & Yes & Yes \\
\hline Hh. assets & Yes & Yes & Yes & Yes & Yes & Yes & Yes & Yes & Yes & Yes & Yes & Yes \\
\hline Observations & 2123 & 2123 & 2123 & 2123 & 2123 & 2123 & 2123 & 2123 & 2123 & 2123 & 2123 & 2123 \\
\hline
\end{tabular}


Table A.3: The gender of the first-born and the composition of the households - $2 \mathrm{~d}$ born

\begin{tabular}{llllllll}
\hline & OLS & OLS & OLS & IV - 1st & IV - 2d & IV - 2d & IV - 2d \\
\hline Births & $0.45^{* * *}$ & $0.49^{* * *}$ & $-0.04^{*}$ & & $-0.40^{*}$ & $0.27^{* *}$ & $-0.66^{* * *}$ \\
& $(17.17)$ & $(29.09)$ & $(-1.79)$ & & $(-1.68)$ & $(2.10)$ & $(-3.73)$ \\
2nd born girl & & & & $0.46^{* * *}$ & & & \\
& & & & $(5.96)$ & & & \\
1st born girl & $-0.54^{* * *}$ & -0.09 & $-0.44^{* * *}$ & $0.51^{* * *}$ & -0.11 & 0.02 & -0.13 \\
& $(-5.95)$ & $(-1.61)$ & $(-6.49)$ & $(6.70)$ & $(-0.67)$ & $(0.22)$ & $(-1.04)$ \\
Hh characteristics & Yes & Yes & Yes & Yes & Yes & Yes & Yes \\
Hh. assets & Yes & Yes & Yes & Yes & Yes & Yes & Yes \\
\hline Observations & 2047 & 2047 & 2047 & 2047 & 2047 & 2047 & 2047
\end{tabular}

ç

Standard errors in parentheses $\left({ }^{*} p<0.1,{ }^{* *} p<0.05,{ }^{* * *} p<0.01\right)$. All regressions include time

and district fixed effects. They also include these controls: household head's age, civil status,

number of spouses, ethnicity and the households productive assets, land and cows owned average

education of adult members and a dummy for the ownership of a non-farm business.

The estimates are robust to the exclusion of those controls. 
Table A.4: The number of girls among the children and the household size

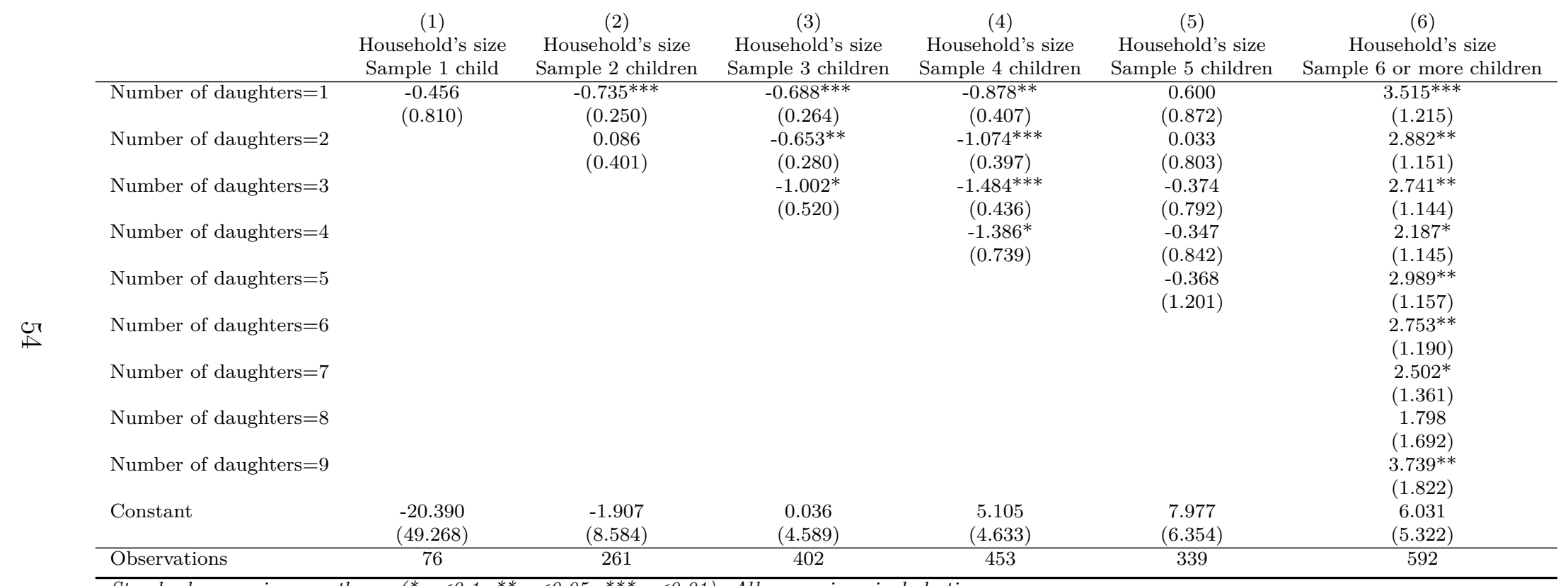

Standard errors in parentheses $\left.{ }^{*} p<0.1,{ }^{* *} p<0.05,{ }^{* * *} p<0.01\right)$. All regressions include time

and district fixed effects. They also include these controls: household head's age, civil status,

number of spouses, ethnicity and the households productive assets, land and cows owned average

education of adult members and a dummy for the ownership of a non-farm business.

Each column corresponds to an ols regression of the household size on the proportion of girls among the children born, in a particular sub-sample.

Column 1 includes all households that have only 1 child, column two: two children, column 3: three children, etc. 
Table 5: The number of children and the number of fostered children

$\begin{array}{llll} & (1) & (2) & (3) \\ & \text { Fostered } & \text { Children } & \text { Fostered } \\ \text { Children } & -0.003 & & -0.019 \\ & (0.005) & & (0.034) \\ \text { 1st born girl } & & 0.514^{* * *} & \\ & & (0.079) & \\ \text { Hh characteristics } & \text { Yes } & \text { Yes } & \text { Yes } \\ \text { Hh. assets } & \text { Yes } & \text { Yes } & \text { Yes } \\ \text { Observations } & 2123 & 2123 & 2123\end{array}$

The dependent variable is the number of fostered children in the household.

We use the sample of older women (age 40-50) where the main results hold.

Standard errors in parentheses ( ${ }^{*} p<0.1$, ** $p<0.05$, *** $\left.p<0.01\right)$.

All regressions include time fixed effects. Hh. controls include the household head's age, civil status

the head's ethnicity and households productive assets. Productive assets include land and cows owned, average education of adult members and a dummy for the ownership of a non-farm business. 